\title{
ФІТОСАНІТАРНИЙ СТАН ПОСІВІВ СОНЯШНИКУ В УМОВАХ ПІВНІЧНО-СХІДНОГО ЛІСОСТЕПУ УКРАЇНИ
}

\author{
Деменко Віктор Михайлович \\ кандидат сільськогосподарських наук, доцент \\ Сумський національний аграрний університет, м. Суми, Україна \\ ORCID: 0000-0002-8264-2802 \\ Vicmix64@ukr.net \\ Голінач Оксана Леонідівна \\ начальник управління фітосанітарної безпеки \\ Головне управління Держпродспоживслужби в Сумській області, м. Суми, Україна \\ hovoruno@gmail.com \\ Власенко Володимир Анатолійович \\ доктор сільськогосподарських наук, профресор \\ Сумський національний аграрний університет, м. Суми, Україна \\ ORCID: 0000-0002-5535-6747 \\ vlasenkova@ukr.net
}

Висока економічна ефективність вирощування соняшнику сприяла різкому збільшенню площ, посівів соняшнику в Сумській області. Збільшення посівних площ соняшнику призводить до перенасичення сівозмін цією культурою. Вивчення фітосанітарного стану посівів соняшнику проводили у базових господарствах управління фітосанітарної безпеки головного управління Держпродспоживслужби в Сумській області. Методика досліджень була загальноприйнятою.

Основними шкідниками в посівах соняшнику були сірий буряковий довгоносик (Tanymecus palliatus Fabr.), личинки ковалика посівного (Agriotes sputator L.), мідляк піщаний (Opatrum sabulosum L.), личинки західного травневого хруща (Melolontha melolontha L.), геліхризова попелиия (Brachycaudus helichrysi Kalt.).

Сходи соняшнику пошкоджували сірий буряковий довгоносик, мідляк пішаний. Серед грунтових шкідників найбільш розповсюджені були личинки західного травневого хруща та личинки коваликів.

Геліхризова попелиця заселяла посіви соняшнику у фазу 6-8 пар справжніх листків. На посівах соняшнику попелиця продовжувала розселятися по полю у фази утворення суцвіть та початку цвітіння соняшнику. Найвища заселеність соняшнику спостерігалася по краю поля в 2015, 2017 роках і становила 16 \% рослин. В середині поля заселеність рослин попелицею була нижчою, ніж по краю.

За роки досліджень перевищення економічного порогу шкодочинності ураженості шкідниками посівів соняшнику було лише в окремі роки. Пошкодженість соняшнику довгоносиком буряковим сірим, личинками ковалика посівного, мідляком піщаним, личинками хруща травневого західного була слабкою, а їх чисельність незначна.

Збільшення посівних площ соняшнику не призвело до суттєвого зростання чисельності шкідників, перевищення ними економічного порогу шкодочинності.

Ключові слова: соняшник, сірий буряковий довгоносик, ковалик посівний, мідляк піщаний, західний травневий хрущ, геліхризова попелиця, чисельність шкідників, пошкодженість рослин, заселеність рослин.

DOI: https://doi.org/10.32845/agrobio.2019.4.1

Вступ. Серед олійних культур соняшник має найбільші посівні площі в Україні, а олія соняшникова займає $90 \%$ від її загального виробництва. Як зазначають Деменко В. М. та інші [1], у Сумській області у 2005 році посівна площа соняшнику становила 30,0 тис. га, а у 2014 р. - 164,5 тис. га, що склало у структурі посівних площ відповідно 3,3 \% та 18,2 \%, що більше, ніж у 5 разів.

За даними рис. 1, у 2015 р. спостерігалося незначне зменшення площ посівів соняшнику, порівняно з 2014 р. до

163,6 тис. га, або 17,7 \% у структурі посівних площ. У 2016 р. збільшилася посівна площа соняшнику до 169,2 тис. га, що становило у структурі посівних площ 18,3 \%. У 2017-2018 роках спостерігається значне збільшення посівних площ та насиченість соняшником сівозміни. У 2017 р. дану культуру висівали на площі 188,3 тис. га, у 2018 р. - 202,8 тис. га, що склало у структурі посівних площ, відповідно, 19,9\% та $21,0 \%$. 


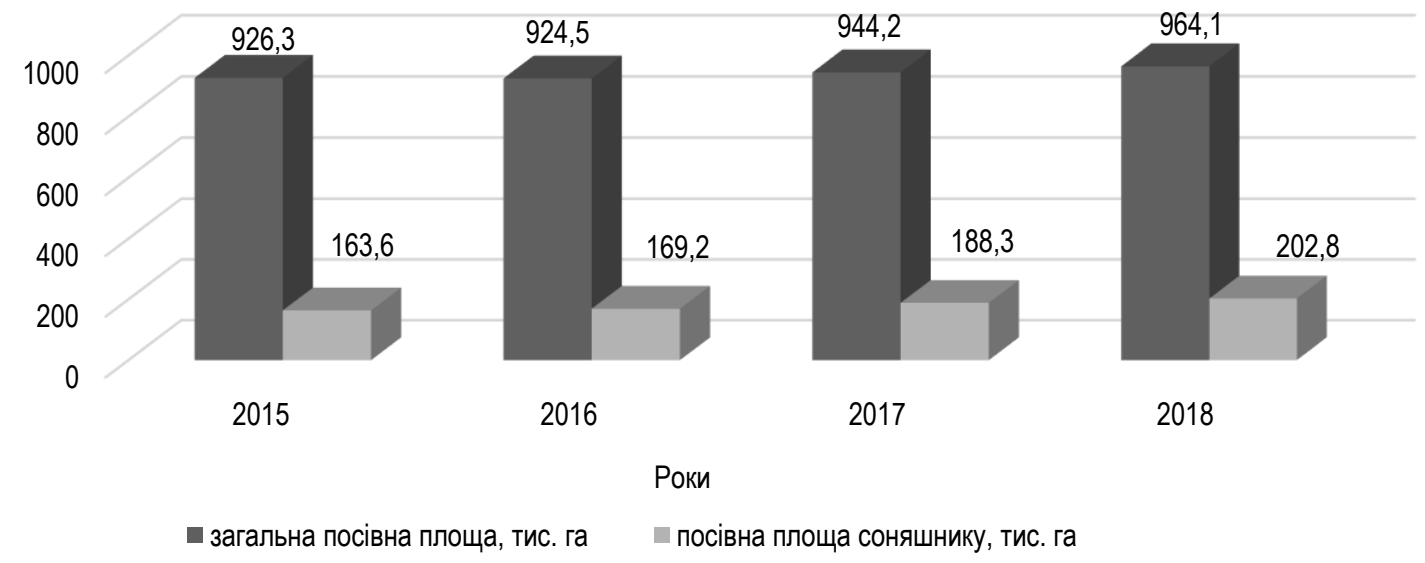

Рис. 1. Загальна посівна площа та посівна площа соняшнику в Сумській області у 2015-2018 роках

Збільшення посівних площ соняшнику призводить до перенасичення сівозмін цією культурою, що має негативні наслідки: зниження родючості ґрунтів, значне пересушування грунту, погіршення якості зерна, зниження урожайності. У результаті значного збільшення площ вирощування соняшнику в ґрунті накопичуються збудники хвороб, запаси спеціалізованих та багатоїдних шкідників, які розвиваються впродовж періоду вегетації соняшнику.

Як вказують П. І. Бойко [2], А. В. Кохан [3] й А. В. Фокін [4] у сівозміні соняшник повертається через 7-10 років та те саме поле, тобто в сівозміні у структурі посівних площ він займає 10-13 \%. Це дає можливість зменшити запаси спеціалізованих, багатоїдних шкідників, підвищити запаси продуктивної вологи ґрунту, покращити фітосанітарний стан сільськогосподарських культур. У Сумській області площі посівів соняшнику зросли, у тому числі і за рахунок розширення ареалу вирощування культури у північних районах області [1]. Тому зважаючи на значне зростання посівів соняшнику виробничники ведуть дискусію щодо зменшення терміну повернення даної культури у сівозміні через два роки. Насіннєва фірма «МНАГОР» при вирощуванні соняшнику по соняшнику у 2009-2011 роках отримала результати, які свідчать про значну ураженість посівів вовчком соняшниковим, де вона становила $80 \%$, а також про збільшення чисельності ґрунтових шкідників на 30 \%, порівняно з варіантом, де соняшник вирощувався у сівозміні. Запровадження сівозміни сприяло зменшенню вовчка соняшникового до $13 \%$ [5].

Мета досліджень полягала у вивченні динаміки чисельності шкідників посівів соняшнику та пошкодженість рослин в умовах північно-східного Лісостепу України.

Матеріали і методи досліджень. Дослідження щодо вивчення динаміки чисельності, пошкодженості рослин соняшнику багатоїдними та спеціалізованими шкідниками проводили у 2015-2018 рр. у базових господарствах управління фітосанітарної безпеки головного управління Держпродспоживслужби в Сумській області. Методика досліджень була загальноприйнята [6]. Для визначення чисельності довгоносика бурякового сірого, мідляка піщаного обліки проводили на ділянках розміром 0,25 м². Пошкодженість сходів шкідниками визначали шляхом огляду 100 рослин (по 10 рослин у 10 місцях) по діагоналі поля. Облік личинок хруща травневого західного, ковалика посівного проводили методом ґрунтових розкопок. Попелицю геліхризову обліковували на 100 рослин у крайовій смузі з чотирьох боків поля, по 25 рослин з кожного боку, та на 100 рослинах по двох діагоналях (50 рослин по кожній діагоналі).

Результати та їх обговорення. В умовах Сумської області соняшник пошкоджували багатоїдні шкідники: сірий буряковий довгоносик, піщаний мідляк, личинки західного травневого хруща, коваликів, геліхризова попелиця. Для довгоносика бурякового сірого (Tanymecus palliatus Fabr.), після різкого зменшення посівів цукрових буряків, багаторічних бобових трав, гороху, соняшник став основною кормовою культурою. Жуки заселяли посіви соняшнику у фазу сходів. За даними рис. 2 чисельність довгоносика у 2015, 2017 роках становила 0,4 особ./м², пошкодженість рослин - $7 \%$. У 2016 , 2018 роках шкідник за чисельності 0,2 особ./м² пошкодив $7 \%$ рослин.

Мідляк піщаний (Opatrum sabulosum L.) заселяв посіви соняшнику у фазу сходів. Його чисельність була у 20152017 роках 0,3 особ./м², жуки пошкодили $1 \%$ соняшнику. У 2018 році збільшилася чисельність шкідника до 0,4 особ./м², а пошкодженість рослин - до $2 \%$ (рис. 2).

Серед ґрунтових шкідників найбільш розповсюджені личинки західного травневого хруща та личинки коваликів дротяники. Вони пошкоджували висіяне насіння, проростки, корені соняшнику. За даними рис. 3 чисельність личинок хруща травневого західного була більша, ніж дротяників, але менша економічного порогу шкідливості. Пошкодженість становила 3,0 \% рослин, а чисельність шкідника - 0,7 особ./м². 


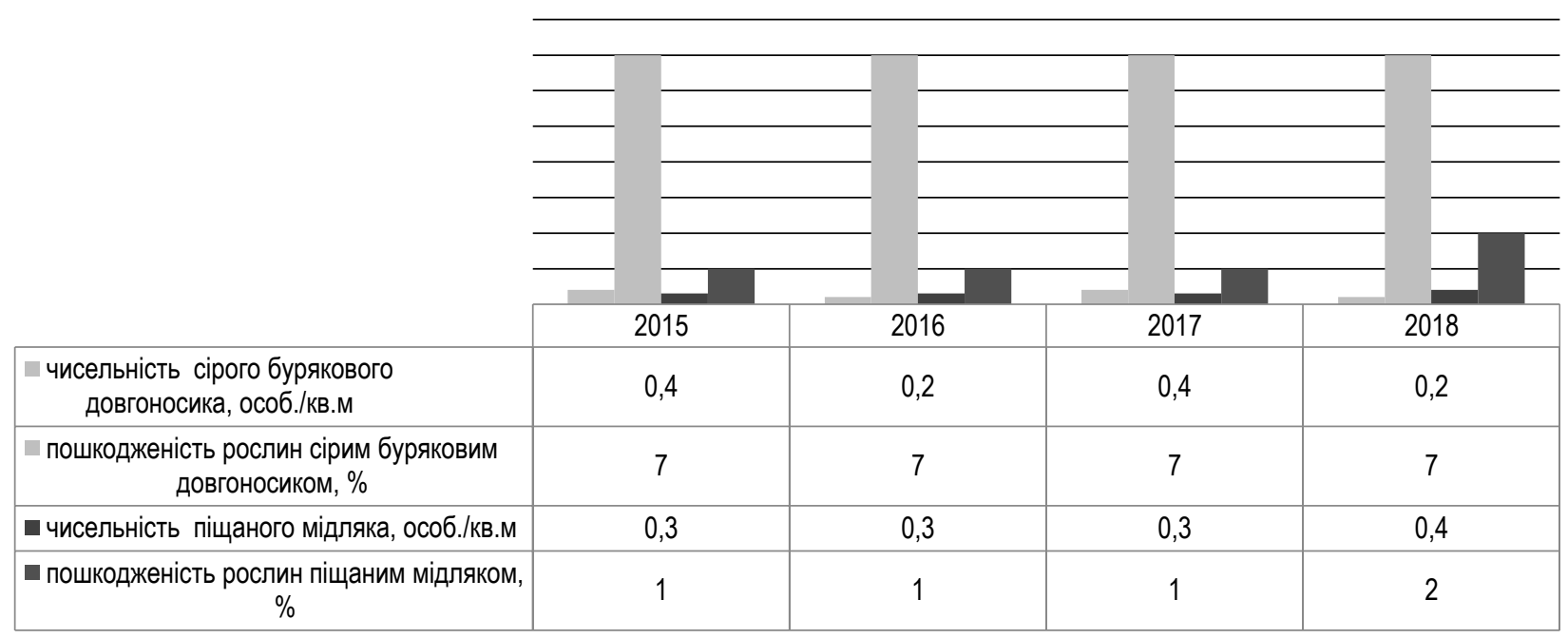

Рис. 2. Чисельність мідляка піщаного, довгоносика бурякового сірого та пошкодженість рослин у фазу сходів, 2015-2018 рр.

Чисельність дротяників у 2015, 2017 роках становила 0,3 особ./М², а пошкодженість рослин склала 2,0 \%. У 2016,
2018 роках збільшилася чисельність шкідника до 0,4 особ./м², пошкодженість соняшнику - до 3,0 \% (рис. 3).

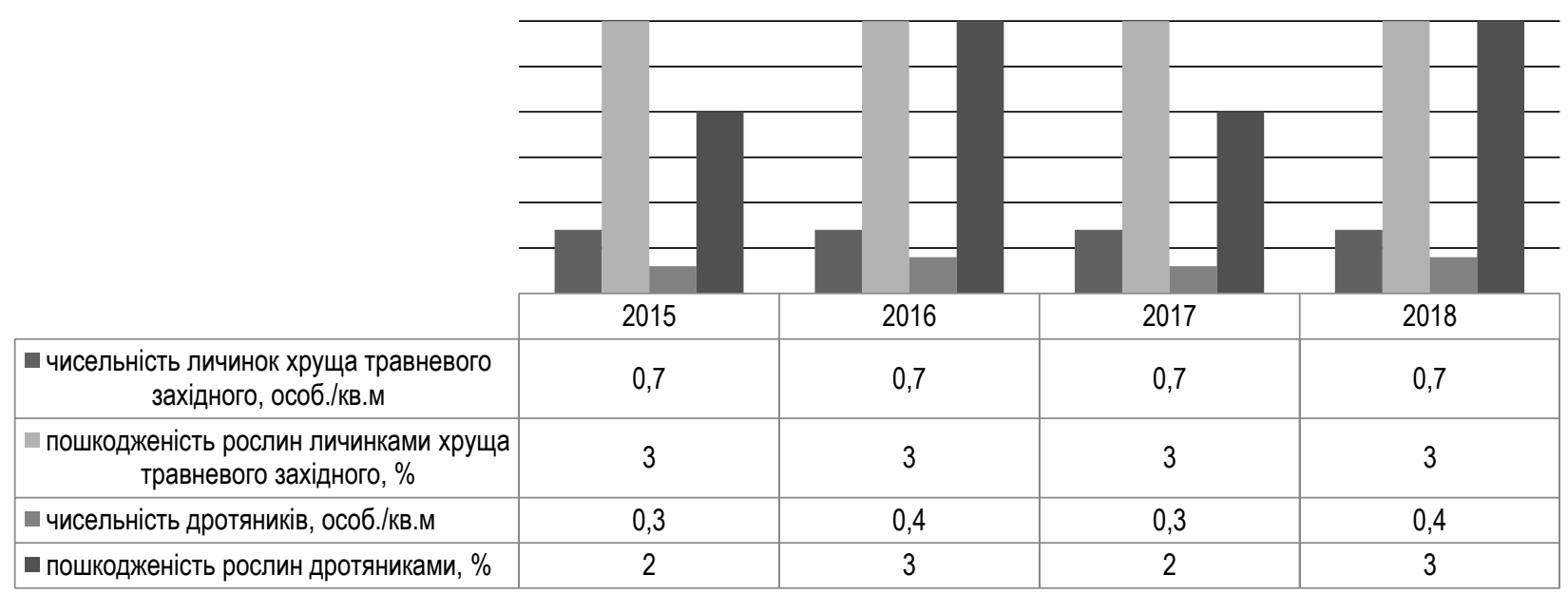

Рис. 3. Чисельність дротяників, личинок хруща травневого західного та пошкодженість рослин у фазу сходів, 2015-2018 pp.

у 2015-2018 роках Brachycaudus helichrysi була найбільш розповсюдженим і шкодочинним шкідником соняшнику. У фразі 6-8 пар листків крилаті самки-розселювачки були виявлені переважно у крайовій смузі. Личинки та безкрилі самки продовжували розселятися по посівах соняшнику у фазу утворення суцвіть-початок цвітіння. Вони утворювали колонії з нижнього боку листків і висмоктували сік, що приводило до деформації листової поверхні. Так як шкідник починав заселяти посіви з краю поля, то протягом періоду вегетації його чисельність і пошкодженість посівів там була більшою в порівнянні з серединою поля. У 2015, 2017 роках в крайовій смузі геліхризова попелиця була відмічена на 16,0 \% рослин, в середній частині поля - на 12,0 \% посівів соняшнику. Спостерігався циклічний розвиток шкідника у 2015-2018 роках. У 2016 та 2018 роках чисельність попелиці та пошкодженість рослин зменшилася і вона була заффіксована на 14,0 \% рослин у крайовій смузі та 8,0\% соняшнику в середній частині поля (рис. 4). 


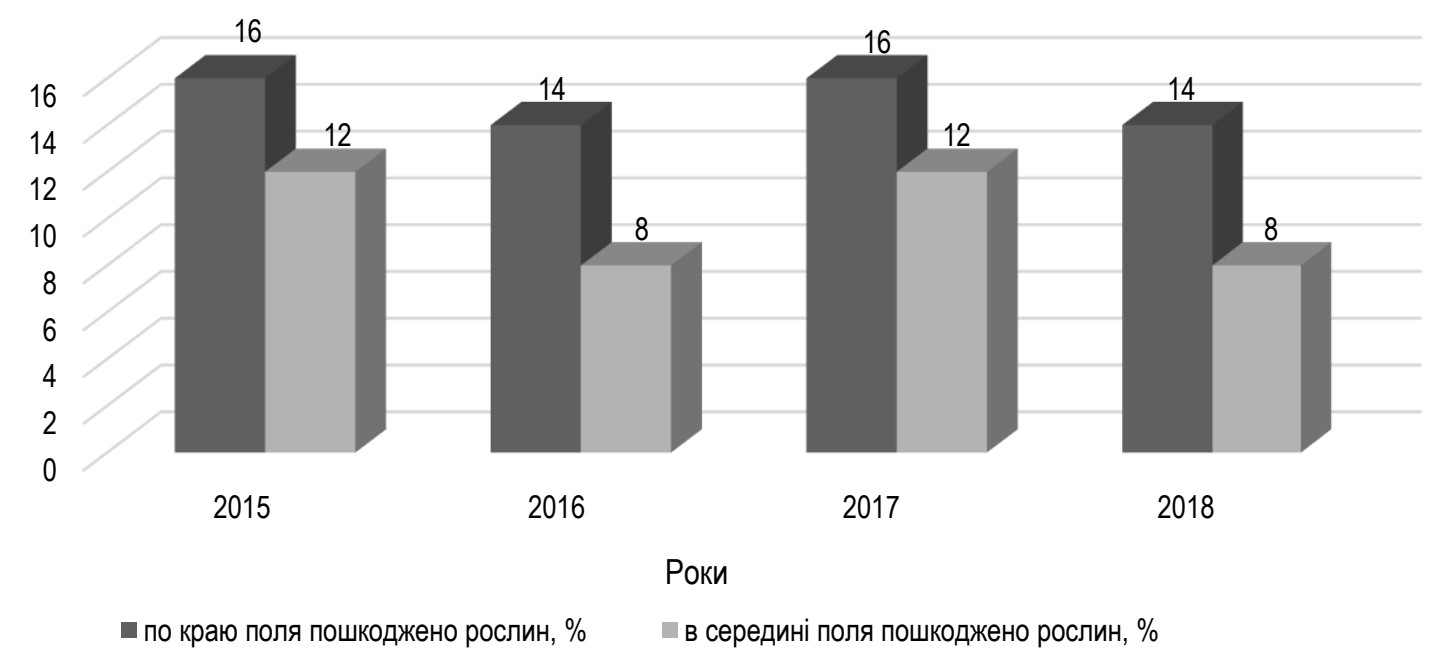

Рис. 4. Заселеність соняшнику попелицею, 2015-2018рр.

Висновки. За результатами досліджень у 20152018 роках відбулася суттєва зміна структури посівних площ у Сумській області. Соняшник за площею посіву посідає третє місце після кукурудзи та пшениці озимої. Насиченість сівозміни соняшником значно збільшилася і становила у 2015 p. $17,7 \%, 2016$ p. $-18,3 \%, 2017$ p. $-19,9 \%, 2018$ p. $-21,0 \%$, що не відповідає науково-обірунтованій системі ведення сівозмін у області. За результатами багаторічних досліджень у базових господарствах управління фітосанітарної безпеки головного управління Держпродспоживслужби в Сумській області найбільш розповсюдженими шкідниками соняшнику були попелиця геліхризова, довгоносик буряковий сірий, мідляк піщаний та грунтові шкідники: личинки ковалика посівного (дротяники), хруща травневого західного.

У 2015-2018 рр. найбільш розповсюдженою була попелиця геліхризова, але перевищення економічного порогу шкодочинності спостерігалося лише по краю поля та у 2015, 2017 роках в середині поля. Пошкодженість соняшнику довгоносиком буряковим сірим, мідляком піщаним, дротяниками, личинками хруща травневого західного була слабкою, а їх чисельність незначна.

Таким чином, збільшення посівних площ соняшнику не призвело до суттєвого зростання чисельності шкідників, перевищення ними економічного порогу шкодочинності.

\section{Бібліографрічні посилання:}

1. Demenko, V. M., Vlasenko, V. A., Jemec', O. M., Govorun, O. L., \& Hil'ko, N. V. (2015). Dynamika chysel'nosti shkidnykiv sonjashnyku v umovah pivnichno-shidnogo Lisostepu Ukrai'ny. [Dynamics of the number of sunflower pests in the conditions of the North-Eastern Forest-Steppe of Ukraine]. Visnyk Sums'kogo NAU. Serija «Agronomija i biologija», 9(30), 94-97 (in Ukrainian).

2. Bojko, P. I., \& Kovalenko, N. P. (2015). Koncentraciya i rozmishhennya kul'tur u sivozminax [Concentration and placement of crops in rotation]. Propozyciya, 12, 74-78 (in Ukrainian).

3. Kohan, A. V., Len', O. I., \& Cyljuryk, O. I. (2016). Naslidky nasychennja sivozmin sonjashnykom [Consequences of saturation of sunflower rotations]. Naukovo-tehnichnyj bjuleten' Instytutu olijnyh kul'tur NAAN, 23, 131-136 (in Ukrainian).

4. Fokin, A. V. (2010). Systema zahystu sonjashnyku vid shkidnykiv [System of protection of sunflower from pests]. Propozycija, 3, 82-88 (in Ukrainian).

5. Tehnologija vyroshhuvannja sonjashnyku [Sunflower growing technology]. Sajt pryvatne pidpryjemstvo «MNAGOR». [Electronic resource]. Access mode: http://www.mnagor.com.ua (in Ukrainian).

6. Gorbunov, A. F., Tatarynova, V. I., Demenko, V. M., \& Sarbash, V. M. (2009). Metodychni vkazivky po vyjavlennju ta obliku shkidnykiv ta hvorob sonjashnyku dlja studentiv special'nosti «Zahyst roslyn» [Guidelines for the detection and accounting of sunflower pests and diseases for students of the specialty "Plant Protection"]. Sumy, SNAU (in Ukrainian).

Demenko V. M., PhD (Agricultural Sciences), Associate Professor, Sumy National Agrarian University, Sumy, Ukraine

Golinach O. L., Head of the Phytosanitary Safety Department, Main department of the state Consumer service in Sumy region, Sumy, Ukraine

Vlasenko V. A., Doctor (Agricultural Sciences), Professor, Sumy National Agrarian University, Sumy, Ukraine

THE PHYTOSANITARY STATUS OF SUNFLOWER CROPS OF NORTH-EASTERN FOREST-STEPPE OF UKRAINE.

The high economic efficiency of sunflower growing contributed to a sharp increase in the sunflower planting acreage in Sumy region. The increase of cultivated areas under sunflower resulted in an oversaturation of crop rotations with this crop. The study of the phytosanitary status of sunflower crops was carried out in the basic farms of the phytosanitary security department of the Main Office of State Consumer Service (Derzhprodsluzhba) in Sumy region. The research methodology was commonly accepted.

The main pests of sunflower crops were grey beet weevil (Tanymecus palliates Fabr.), larvae of common click beetle (Agriotes sputator L.), darkling beetle (Opatrum sabulosum L.), larvae of the western may beetle (Melolontha melolontha L.), leafcurl plum aphid 
(Brachycaudus helichrysi Kalt).

The sunflower seedlings were damaged grey beet weevil, darkling beetle. The most widespread soil pests were the larvae of the western may beetle and larvae of common click beetle.

Leafcurl plum aphid populated sunflower crops with 6-8 pairs of true leaves. It continued to spread across the field during the inflorescence stage and the stage of initial blossom. The highest pest colonization was observed at the edge of the field in 2015, 2017 and accounted for $16 \%$ of the plants. In the middle of the field, the aphid colonization was lower than at the edge.

During the years of research, the economic threshold of sunflower pest harmfulness was exceeded only in some years. Sunflower damage by grey weevil beet, larvae of common click beetle, darkling beetle, larvae of the western may beetle was weak, and their number was insignificant.

The increase of sunflower acreage did not lead to a significant growth of pest number, the exceeding of economic threshold of their harmfulness.

Key words: sunflower, grey weevil beet, larvae of common click beetle, darkling beetle, larvae of the western may beetle, leafcurl plum aphid, number of pests, plant damage, pest colonization of plants.

Деменко В. М., кандидат сельскохозяйственных наук, доцент, Сумской национальный аграрный университет, г. Сумы, Украина

Голинач О. Л., начальник управления фитосанитарной безопасности, Главное управление Госпродпотребслужбы в Сумской области, г. Сумы, Украина

Власенко В. А., доктор сельскохозяйственных наук, профеессор, Сумской национальный аграрный университет, е. Сумы, Украина

ФИТОСАНИТАРНОЕ СОСТОЯНИЕ ПОСЕВОВ ПОДСОЛНЕЧНИКА В УСЛОВИЯХ СЕВЕРО-ВОСТОЧНОЙ ЛЕСОСТЕПИ УКРАИНЫ

Высокая экономическая эффрективность выращивания подсолнечника способствовала резкому увеличению площади сева подсолнечника в Сумской области. Увеличение посевных площадей подсолнечника приводит к перенасыщению севооборотов этой культурой. Изучение фитосанитарного состояния посевов подсолнечника проводили в базовых хазяйствах управления фитосанитарной безопасности главного управления Госпродпотребслужбы в Сумской области. Методика исследований была общепринятой.

Основными вредителями в посевах подсолнечника были серый свекловичный долгоносик (Tanymecus palliatus Fabr.), личинки щелкуна посевного (Agriotes sputator L.), медляк песчаный (Opatrum sabulosum L.), личинки западного майского жука (Melolontha melolontha L.), гелихризовая тля (Brachycaudus helichrysi Kalt.).

Всходы подсолнечника повреждали серый свекловичный долгоносик, медляк песчаный. Среди почвенных вредителей наиболее распространенными были личинки западного майского жука и личинки щелкунов.

Гелихризовая тля заселяла посевы подсолнечника в фазу 6-8 пар настоящих листьев. В посевах подсолнечника тля продолжала расселяться по полю в фазе образования соцветий и начале цветения подсолнечника. Самая высокая заселенность подсолнечника наблюдалась по краю поля в 2015, 2017 годах и составляла 16 \% растений. В средине поля заселенность растений тлей была ниже, чем по краю.

За годы исследований превышение экономического порога вредоносности вредителями посевов подсолнечника было лишь в отдельные годы. Повреждение подсолнечника долгоносиком свекловичным серым, личинками щелкуна посевного, медляком песчаным была слабой, а их численность незначительна. Увеличение посевных площадей подсолнечника не привело к существенному росту численности вредителей, превышение ими экономического порога вредоносности

Ключевые слова: подсолнечник, серый свекловичный долгоносик, щелкун посевной, медляк песчаный, западный майский хрущ, гелихризовая тля, численность вредителей, повреждение растений, заселенность растений.

Дата надходження до редакції: 15.09.2019 p. 